\title{
Sciendo
}

Administration, vol. 67, no. 1 (2019), pp. 15-24

doi: 10.2478/admin-2019-0003

\section{Local government, 2018}

\author{
Bríd Quinn \\ University of Limerick, Ireland
}

From the abolition of library fines and the creation of age-friendly communities to the completion of thousands of social housing units and the announcement of a '21st Century University Town', 2018 proved a busy year for local authorities. It was a year in which much data on the performance of local authorities were disseminated. The Local Government Audit Service's report for 2016 (published in 2018) noted an improvement in some local authorities in revenue-collection yields, budgetary control, procurement, capital balances and governance. The National Oversight \& Audit Commission (NOAC) continued to oversee the implementation of national policy at local government level, producing reports on performance indicators and the Public Spending Code, as well as a report on customer satisfaction levels and three reports on auditing issues. NOAC also continued its profiling of local authorities, visiting councils to enable NOAC members to gather and interrogate data on topics such as finances, customer service, corporate planning, housing issues, performance indicators, tourism initiatives, employment, and economic and community development.

\section{Housing issues}

Ambitious targets had been set for social housing in 2018 and local authorities worked earnestly to meet them. The Rebuilding Ireland social housing building report for Quarter 3 of 2018 showed that 2,369 social housing units had been built by the end of September. This 
represented less than half ( 48 per cent) of the annual target but it was expected that many more units would be completed by the end of the year. However, the report indicated that targets for Housing Assistance Payment and Rental Accommodation Scheme tenancies would likely be met by the end of the year. In April the Minister for Housing, Planning and Local Government, Eoghan Murphy, TD, provided each local authority with a 2018-21 housing target reflecting the annualised national target under Rebuilding Ireland. The targets will ensure that housing remains a top priority for local authorities.

NOAC's Report on Performance Indicators 2017, published in July, showed that at the end of 2017, local authorities had 133,394 dwellings in their ownership, an increase on the 131,375 dwellings of 2016. It disclosed that only 2.72 per cent of local authority houses were vacant at the end of 2017 compared to 3 per cent at the end of 2016 and 3.8 per cent at the end of 2014. It also showed that 13 local authorities had a vacancy rate of less than 2 per cent in 2017. The NOAC report indicated that there were 5,263 homeless adults in emergency accommodation at the end of 2017 but figures for November 2018 showed 6,157 adults accessing local authority managed emergency accommodation (Department of Housing, Planning and Local Government, 2018). Thus, homelessness persists as a major issue for all levels of government.

Some central directives caused controversial reactions. In March a letter sent to local authorities from the Department of Housing, Planning and Local Government warned councillors against interfering in planning applications and discussing them at municipal district/local area committees, as it could 'undermine due process and exert undue influence' on planning authorities (McMorrow, 2018). On 7 December restrictions on maximum building heights in towns and cities were lifted in the Urban Development and Building Heights Guidelines for Planning Authorities. The guidelines, which remove height caps on new buildings, are aimed at preventing urban sprawl and were published following a public consultation process.

\section{Financial and economic issues}

Income sources showed little change in 2018. Commercial rates accounted for almost one-third of all local authority income in 2018, totalling $€ 1.5$ billion ( 31.5 per cent), followed by grants and subsidies (from central government) at $€ 1.45$ billion ( 30.3 per cent), and goods and services at $€ 1.41$ billion ( 29.5 per cent). The Local Property Tax 
(LPT) provided $€ 395$ million, or 8.2 per cent of total income. The issue of reviewing LPT valuations emerged several times during 2018 but no definitive proposals have yet been published. This is likely to be a controversial issue in the lead up to the 2019 local elections.

Not surprisingly, housing was the largest section of budgeted expenditure for local authorities, amounting to $€ 1.47$ billion, or 30.6 per cent of total expenditure. It was followed by roads (19 per cent) and environmental services (13.6 per cent) (Farrell, 2018).

While no major reform of local government finance happened during 2018, the topic was widely discussed. The Committee of Public Accounts (PAC) Periodic Report Number 3, published in July, contained a number of recommendations regarding local government funding. The report advocated further examination of the distribution of local government funding, a review of the flows of funds from central government to local government in order to simplify the process, and proactive engagement with local authorities by central government bodies to ensure clarity about planned funding provision.

Minister Murphy established a review group to consider the methodology used for determining local authority funding baselines to inform the distribution of available funding for general purposes. The review aims to develop a methodology for distributing the available funding that brings greater balance and equity of funding outcomes for local authorities. In conjunction with the review a stakeholder consultation process was put in place focusing on indicators and data sources that could be applied across the local government sector to review baselines and guide the allocation of non-infrastructure funding. Details of the outcome of the review have yet to become public.

In addition to the normal funding sources, many funding opportunities arose for local authorities during 2018 - among them, the $€ 4$ billion allocated from Project Ireland 2040 funds for rural development, urban regeneration, climate action and innovation. For example, eighty-eight projects are to be allocated a total of $€ 100$ million under the Urban Regeneration and Development Fund. Money is allocated competitively to the best projects which leverage investment from other sources. There is a requirement for local authorities applying for this fund to invest at least 25 per cent of the total project value from other sources, including their own resources and/or complementary investments.

During 2018 local authorities continued to embed their economic development role as they sought to implement the local economic and 
community plans, approved by the local community development committees. Local enterprise offices (LEOs) continue to play an important role. The LEO Impact Report 2017 showed that by the end of 2017 , there were 37,485 people employed by 7,182 small businesses and start-ups that had received financial assistance from LEOs (Enterprise Ireland, 2018).

Brexit implications created uncertainties for local authorities, particularly those in border regions. Business and economic development, tourism, FDI, services, infrastructure, retail and environmental standards are among the issues of concern. Local authorities and LEOs have been raising awareness and building local capacity and capability in anticipation of what may happen after 29 March 2019.

\section{Climate change adaptation and environmental issues}

There were many developments regarding climate change, sustainability and environmental issues in Irish local government during 2018. The National Adaptation Framework, launched in January 2018, announced funding of $€ 10$ million over a five-year period to establish four local authority regional climate action offices to support the implementation of national climate policy. Late in the year Local Authority Adaptation Strategy Development Guidelines were issued to assist local authorities in producing their strategies, which will form a key part of Ireland's climate change adaptation approaches.

The Sustainable Development Goals National Implementation Plan 2018-2020 recognises the role of local authorities in achieving sustainability, urging them to assess the key risks and vulnerabilities of climate change, implement climate resilience actions and ensure climate adaptation considerations are mainstreamed into all local policymaking. The plan also highlights the importance of participatory approaches, specifying public participation networks as a means of ensuring inclusive decision-making and reinforcing the role of local authorities.

Already, local authorities have shown their awareness of sustainability issues in their institutional practices. Local authorities were responsible for 21.7 per cent of the total public sector energy spend in 2017 but were also responsible for 25 per cent of the total public sector primary energy savings (GWh) and performance improvement (Sustainable Energy Authority of Ireland, 2018). 
The River Basin Management Plan 2018-2021 includes many measures aimed at protection and improvement of water quality. These include $€ 1.7$ billion investment in urban waste water treatment infrastructure by 2021, extension of the local authority-led Domestic Waste Water Treatment Systems grant scheme, a new Agricultural Sustainability Support and Advisory Programme to promote best agricultural practice regarding water quality in 190 targeted areas, and establishment of a Local Authority Waters and Communities Office, which will be responsible for the Community Water Development Fund that supports community initiatives to improve water quality.

In May the Office of Public Works published twenty-nine flood risk management plans to address flood risk in Ireland and created an interactive Flood Plans Viewer, outlining the flood risk management measures. As part of the risk management process, more than $€ 14$ million was available to nineteen local authorities to lead on delivery of thirty-one schemes.

\section{Boundary issues}

In preparation for the 2019 local elections, two local electoral area (LEA) boundary committees had been established at the end of 2017. Local Electoral Area Boundary Committee No. 1 was requested to review and make recommendations on the division of local authority areas outside of Dublin, with the exceptions of Cork County, Cork City, Galway County and Galway City. Local Electoral Area Boundary Committee No. 2 was initially requested to review the boundaries in the Dublin councils and later those in Cork City and Galway City. Both committees undertook public consultations, with Committee No. 1 receiving 291 submissions.

The terms of reference for the committees specified that, except in compelling circumstances, the number of councillors assigned to an LEA should be not less than five and not more than seven. This led to significant changes in many counties and cities although the overall number of councillors remains unchanged. In making their recommendations, the committees took into account factors such as population, particularly the extent of urban and rural population density, geography and topography, as well as consideration of community linkages. Consequently, they recommended:

- a greater number of LEAs;

- increased numbers of municipal districts with multiple LEAs; 
- fewer seats in many areas;

- a territorial reduction in many LEAs;

- more manifestly town-focused LEAs, and in cities more LEAs that encompass recognised communities.

The changes were formalised through a series of statutory instruments in December 2018 and January 2019, and will form the basis for the 2019 local elections.

The Cork Boundary issue was the main focus of the Local Government Act, 2018 [91c of 2018], which provides for transfer of part of the administrative area of County Cork to the administrative area of Cork City Council. The Act was signed into law in early 2019 and also deals with matters such as the transfer of assets and liabilities and transitional provisions relating to local authority financial functions within Cork. Both councils have been working on transition arrangements in conjunction with a government-appointed Implementation Oversight Group.

The proposals for a merger of Galway City and County remain contentious. Senate amendments to the Local Government Bill, 2018, led to removal of such proposals from the subsequent Act. Further discussions and legislation are planned for 2019.

\section{How our local authorities are perceived}

Two appraisals published in 2018 offered insights into how our local authorities are perceived. Transparency International Ireland (2018) published a report which ranked Ireland's thirty-one local authorities based on three criteria: transparency, accountability and ethics. Galway City Council topped the National Integrity Index on Local Authorities for 2018, Monaghan County Council had the joint-highest score with Galway City Council in the accountability category, while Dublin City Council and South Dublin County Council had the jointhighest score in the transparency category. It must be remembered that the scores do not indicate which authority is the most or least transparent, accountable or ethical. Rather, the scores identify the authorities with the best systems and practices in place to ensure transparency, accountability and ethics. Despite initial misgivings about the accuracy of some aspects of the report, the County and City Management Association undertook to explore the report's constructive suggestions in order to help improve services. Many local newspapers highlighted their local authority's performance in the survey. 
NOAC (2018) commissioned Ipsos MRBI to conduct a survey of the general public to establish levels of satisfaction with their experience of engaging with their local authority. The report was published in July 2018 and this first phase of research surveyed residents in the ten largest local authority areas (based on population). Overall, 65 per cent of people surveyed said they believed their local authority was working to make their area greener and cleaner, 92 per cent said their local area was a good place in which to live and 84 per cent said they had a strong sense of belonging to where they lived. One in four residents believed they could influence their local authority, and 59 per cent said that their local authority is making a positive contribution and that services have improved. The survey found that the most important services provided by the council fell into three main categories: roads and road safety, housing and amenities, and parks and playgrounds. According to the survey, 37 per cent of respondents thought their local authority was well run, 29 per cent agreed their local authority was transparent, 27 per cent said it provided good value for money, while 40 per cent of respondents felt their local authority was difficult to deal with and too bureaucratic. Only 4 per cent 'know a great deal' about their council. Consequently, knowledge of the council and awareness of the services provided was generally low and satisfaction rates with local authorities were linked to knowledge levels.

These reviews, although limited, are useful indicators of how local authorities are perceived and suggest topics on which local authorities might communicate their roles and achievements more effectively.

\section{Preparing for change}

The year 2018 saw initiation of many measures which may lead to significant change in local government. The recurrent topic of directly elected mayors for our major cities received much attention and the Local Government Act, 2018 [91c of 2018], contains provisions for plebiscites in Cork City, Limerick, Waterford and Galway next May. In Dublin the issue will be referred to a Dublin Citizens' Assembly, which will be convened early in 2019. The roles of the mayors has yet to be specified but statements by the Minister of State for Local Government and Electoral Reform, John Paul Phelan, TD, would intimate that they will have some executive functions and that there will be a recall mechanism included in the electoral system. 
At committee stage of the Local Government Bill, 2018, the government proposed amendments to allow establishment of urban area committees, which would have responsibility for the production of the local area plan for a cross-boundary urban area and its contiguous areas. The section was removed at the report stage but it is likely that the issue will be dealt with in 2019 through separate legislation since there was broad acceptance of the principle underpinning the proposal.

In June Minister Phelan commissioned Sara Moorehead, SC, to carry out a review of the role and remuneration of elected members of local authorities. She submitted an interim report to the government in December. Her review found 'very divergent views' about the role to be played by councillors and she suggests that it will be a difficult task to reconcile positions (Bray, 2018). Having consulted widely, she has sought many clarifications, chief among them being the definition of the current and future role of councillor, a description of councillors' workload since the 2014 local government reforms and assessment of whether that workload can be reduced. Delegates from the Association of Irish Local Government and Local Authority Members Association met with the minister to discuss the interim report. A final report is due in April.

The Programme for a Partnership Government set out a number of requirements in relation to local government reform and these are being addressed. Minister Phelan indicates that his department has so far submitted three policy papers to the Oireachtas, dealing with (i) municipal governance, (ii) local authority boundaries, and (iii) local authority leadership, governance and administration. The papers are not yet publicly available but are likely to be the basis for further reform.

The government has begun work on modernisation of the voter registration process. In the summer of 2018 a consultation process with local authority franchise teams was carried out to get their views on draft proposals. A public consultation process is currently underway. The proposed changes would have implications for local authority elections and also the administration of those elections.

The Department of Rural and Community Development employed consultants to prepare a local digital readiness assessment for each local authority. Among the themes examined were levels of digital literacy, training, qualifications and use; availability and use of online local government resources; and rates of e-commerce and innovation. The assessments enable the public to compare levels of readiness and 
will serve as a basis for local authorities to prepare local digital strategies.

During 2018 innovative five-year culture and creativity strategies were developed by local authority culture teams and local Creative Ireland Programme coordinators. The strategies provide opportunities for local authorities, citizens and local communities to work together to foster and facilitate participation in cultural and creative activities. Their implementation will make more evident the role local authorities play in promoting and supporting cultural activities.

Legislation on local authority accountability is working its way through the Oireachtas. If passed, it will provide a statutory mechanism whereby the minister can implement a binding obligation on local authority staff to issue a full and comprehensive response within fourteen days to local authority member representations submitted on behalf of constituents or community groups. It will also allow the minister to publish quarterly league tables comparing local authority response times across the country. A bill to provide for the granting of discharge licences by a water services authority for the development of single houses is also being debated. Its enactment would have a significant impact on local planning. Substantial change will come about if the Local Government Rates Bill, 2018, is enacted. It proposes to increase the powers of local authorities to levy and collect commercial rates. Similarly, a private members' bill, the Local Government (Restoration Of Town Councils) Bill, 2018, would have profound consequences if it completes the legislative process.

\section{Conclusions}

Local authorities acquitted themselves well during 2018, fulfilling their designated functions and their social, economic and cultural roles. While the media generally concentrates on issues such as housing and homelessness, events such as the Chambers Ireland Excellence in Local Government Awards encapsulate the diverse work being done in the sector. With categories including Best Practice in Citizen Engagement, Joint Local Authority Initiatives, Local Authority Innovation, Outstanding Initiatives through the Municipal Districts, Promoting Economic Development, and Supporting Active Communities and Sustainable Environment, the awards recognise, publicise and affirm the work of councils. Clare County Council was 
the overall winner in 2018, with projects shortlisted in eleven categories. The winning Joint Local Authority Initiative was repairmystuff.ie, an initiative led by Monaghan County Council, in conjunction with other local authorities, the Local Authority Waste Prevention Network and the Environmental Protection Agency.

Impending events such as Brexit, local elections, plebiscites on directly elected mayors and accountability legislation suggest that 2019 will be even busier than 2018 for Irish local government. On the financial front the outlook seems good. In October Minister Murphy welcomed the 22 per cent increase in funding - some $€ 725$ million secured for his department under Budget 2019. Much of the increase will be channelled towards housing and homelessness. However, the increase of $€ 60$ million in the Local Government Fund and $€ 84$ million increase for water services should make a significant difference to other dimensions of local authority work.

\section{References}

Bray, J. (2018, December 6). 'Very divergent views' about role to be played by councillors. Retrieved from https://www.irishtimes.com/news/politics/ very-divergent-views-about-role-to-be-played-by-councillors-1.3721620 [2 February 2019].

Department of Housing, Planning and Local Government. (2018). Homelessness report November 2018. Retrieved from https://www.housing. gov.ie/sites/default/files/publications/files/homeless_report_-_novem ber_2018_0.pdf) [2 February 2019].

Enterprise Ireland. (2018). Impact report 2017. Retrieved from https://www.localenterprise.ie/Documents-and-Publications/ImpactReport-2017-/Impact-Report-2017.pdf [2 February 2019].

Farrell, C. (2018). Local authority budgets in 2018. Retrieved from http://www.publicpolicy.ie/local-authority-budgets-2018 [2 February 2019].

McMorrow, C. (2018). Councillors warned in letter about planning interference. Retrieved from https://www.rte.ie/news/ireland/2018/0316/947958-countycouncillors-planning/ [2 January 2019].

NOAC. (2018). Local authority satisfaction survey 2018. Dublin: NOAC

Sustainable Energy Authority of Ireland. (2018). Annual report 2018 on public sector energy efficiency performance. Retrieved from https:/www.seai.ie/ resources/publications/Public-Sector-Annual-Report-2018.pdf [2 February 2019].

Transparency International Ireland. (2018). National integrity index 2018. Dublin: Transparency International Ireland. 